\title{
Studying of the complexes product of the nerve agent Soman with the Butyrylcholinesterase and Acetylcholinesterase Enzymes
}

\author{
Hassan Hadi*
}

Ammar J. Mohammed**

Mohammed H. Abdallah***

Date of acceptance 9/3/2008

\begin{abstract}
:
Cholinesterases are among the most efficient enzymes known. They are divided into two groups: acetylcholinesterase (AChE) involved in the hydrolysis of the neurotransimitter acetylcholine, and butyrylcholinesterase (BChE) of unknown function. Several crystal structures of the former have shown that the active site is located at the bottom of a deep and narrow gorge. Human $\mathrm{BChE}$ has attracted attention because it can hydrolyze toxic esters and nerve agents. Here we analyze the complexes of cholinesterase with soman by describing the $3 \mathrm{D}$ geometry of the complex, the active site, the changes happened through the inhibition and provide a description for the mechanism of inhibition.

Soman undergoes degradation in the active site of the AChE and BChE. We calculate the energy of the products of the degradation reaction and suggest the reaction path.

The product of the former reaction bind to serine residue in the active site and forming a stable bond and ends the catalytic function of the enzyme.

This study has a useful role in the search of inhibitors to help in the treatment of Alzahimer's disease.
\end{abstract}

\section{Introduction}

Cholinesterases are serine hydrolyses which defined by their ability to hydrolyze choline esters faster than other substrates and by their inhibition by physostigmine (a natural carbamate alkaloid).

Cholinesterases are divided into two subfamilies according to their substrate and inhibitor specificities, acetylcholinesterase (AChE) and butyrylcholinesterase (BChE).

Acetylcholinesterase (AChE) plays a fundamental role in regulating impulse transmission in the central and peripheral nervous systems. Its main function is to terminate the action of the neurotransmitter acetylcholine at the cholinergic synapses and neuromuscular junctions by hydrolyzing it to choline and acetic acid.

AChE is responsible for the hydrolysis of acetylcholine released at the synaptic cleft and the neuromuscular junction in response to nerve action potential [1,2]. In addition, both AChE and $\mathrm{BChE}$ seem to be involved in many roles that are independent of their catalytic activities, such as cell differention and development [3-5] and the approaching diffusion controlled rates [6].

The physiological role of $\mathrm{BChE}$ remains unclear [7-9] although it is capable of hydrolyzing Ach and other acylcholines, so far no endogenous natural

\footnotetext{
*University of Baghdad, College of Science, Chemistry Department

**University of Baghdad, College of Al-Khawrzmi Engineering,Biochemical Department ***University of Baghdad, College of Pharmacy
} 
substrate has been described for this enzyme. Because $\mathrm{BChE}$ is relatively abundant in plasma (about $3 \mathrm{mg} / \mathrm{Liter}$ ) and can degrade a large number of estercontaining compounds it plays important pharmacological and toxicological roles [10,11]. For instance BChE is a potential detoxifying enzyme to be used as a prophylactic scavenger against neurotoxic organophosphates such as the nerve gas Soman [12-18].

$\mathrm{AChE}$ and $\mathrm{BChE}$ share $65 \%$ amino acid sequence homology and have similar molecular forms and active center structure despite being products of different genes on human chromosomes [19]. In the past two decades AChE has been the focus of intense researches aimed at the discovery of efficient inhibitors in view of their use in treating Alzheimer's disease (AD) [20,21]. $\mathrm{AD}$ is the most common cause of dementia in the elderly. It is a chronic, slowly progressive disorder characterized by an impairment of intellectual capacity. This syndrome is associated with widespread neuronal loss and consequent altered neurotransmission regarding several central neurotransmitter systems. The most dramatic abnormalities are those involving the central cholinergic system, thus supporting the foundation of the so-called "cholinergic hypothesis" of AD which postulate that the cognitive decline experienced by ADpatients is due to an extensive loss of cholinergic neurons, especially in certain regions of the brain as the neocortex, the hippocampus, and the amygdale [22-24].

Soman (Pinacoloxymethylphosphoryl Fluoride) $[25,26]$ figure (1) is a colorless liquid and has been described of having an odor of fruit or camphor.<smiles>CC(OP(C)(=O)P)C(C)(C)C</smiles>

Soman (GD)

Fig (1) Molecular structure of nerve agent Soman (Pinacoloxymethylphosphoryl Fluoride)

Visual molecular dynamic (VMD) $[27,28]$ is designed for the calculation, visualization and analysis of biological systems such as proteins, nucleic acids, lipid bilayer assemblies, etc. It may be used to view more general molecules, as VMD can read standard Protein Data Bank (PDB) files and display the contained structure. VMD can be used to animate and analyze the trajectory of a molecular dynamics (MD) simulation.

\section{Calculations}

All calculations were based on the crystal structure of the human AChE and $\mathrm{BChE}$ as complex with Soman [29] from the protein data bank ((1SOM) PDB for AChE and (1P0Q) PDB for BChE).

The three dimensional model of soman was geometrically optimized by means of the PM3 semiemperical Hamiltonian [30] as implemented in the SYBYL graphic interface to MOPAC. Atomic Partial charges for soman molecule were calculated by carrying out single-point ab-initio calculations at the HF/6-31G(d) level using the Gaussian 98 package.

Water molecules were added to the structure by letting GRID program [31] calculates interactions between the protein and a probe representing water. In order to neutralize the charge of the both enzymes 6 and 8 sodium ions were added for AChE and $\mathrm{BChE}$ respectively. 
The geometry of complex, the description of the active site, the interactions and the binding between the enzyme and the substrate where analyzed by VMD program.

\section{Discussion}

Since the AChE and the BChE are belonging to the cholinesterase family, they are close to each other in many characters, BChE enzyme is made up of approximately 530 amino acid carries a few aspargine linked carbohydrate chains. It has also three inter chain disulphide bridges that help to gain specific three dimensional globular structure, figure (2), while the AChE enzyme consists of 535 amino acid and has the three dimensional structure shown in the figure (3).

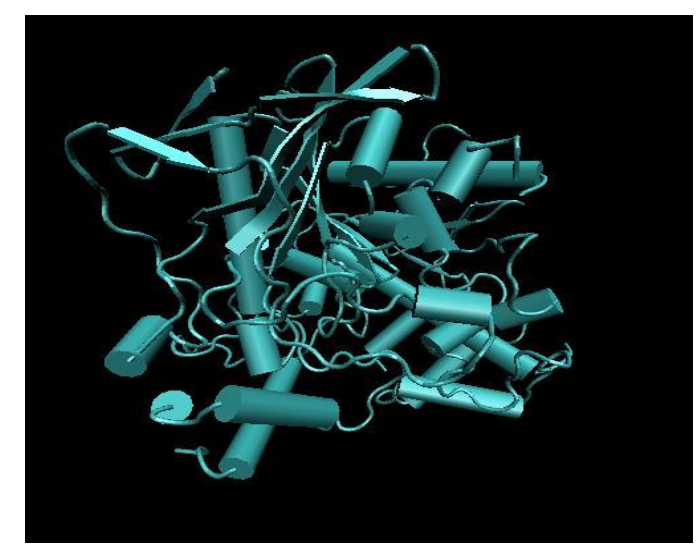

Figure (2) the three dimensional structure of the BChE enzyme

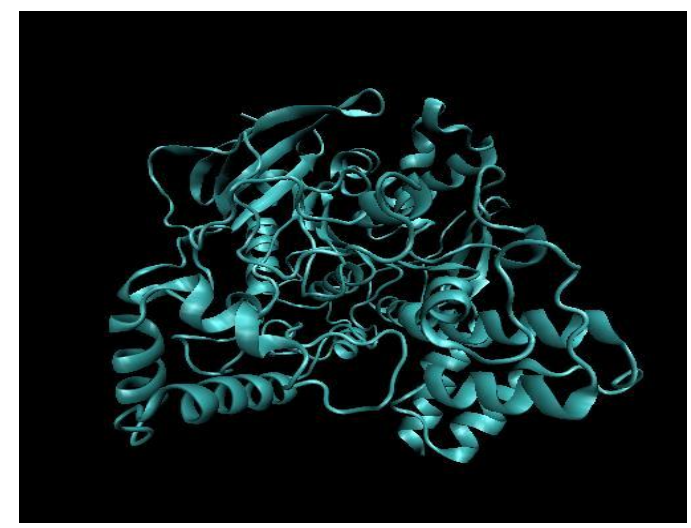

Figure (3) the three dimensional structure of the AChE enzyme
BChE and AChE have a deep and narrow active site gorge lined approximately 55 residues. Peripheral anionic site is located at the mouth of the gorge. Asp70 and Tyr332 residues are involved in the initial binding of positively charged substrate. BChE has a hydrogen bond between Asp70 and Tyr332 which controls the functional architecture of the $\mathrm{BChE}$ active site gorge.

Oxyanion hole found near the choline binding site includes Gly116, Gly117 and Ala199 and helps to rotate the substrate from vertical to horizontal position where the substrate can be hydrolyzed by Ser198.

Acyl binding pocket of AChE and BChE contain different amino acid residues. In acyl binding pocket of AChE, phenyl rings of Phe295 and Phe297 restrict the degree of freedom of the bound substrate and enhance the catalysis of shorter acyl group containing substrate such as buytrylcholine. On the otherhand, Leu286 and Val288 are found in acyl binding pocket of $\mathrm{BChE}$, and replacement of phenylalanines with the aliphatic residues allows the catalysis of large acyl group containing substrate such as butyrylcholine.

Stabilized substrate between oxyanion hole and acyl binding pocket is ready for hydrolysis of the catalytic triad (composed of Ser198, His438 and Glu325) of estratic site of active center.

Figure (4) shows the active site of the complex soman-BChE and the the sequence of the amino acids there, and the same is shown for the active site of the complex soman-AChE in the figure (5). 

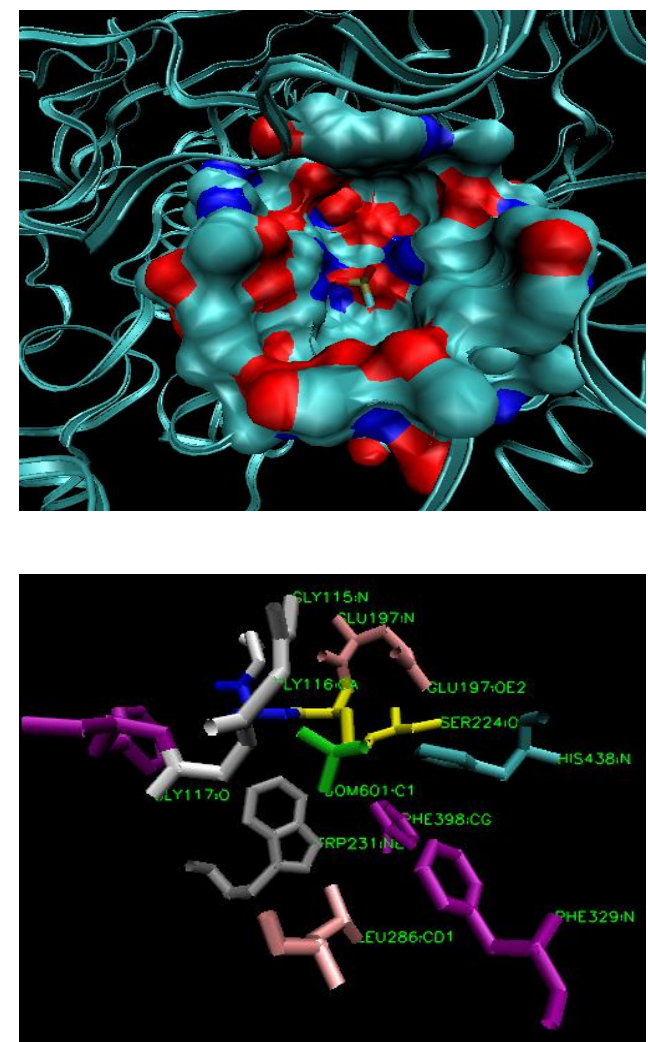

Fig. (4) the active site of the complex somanBChE.
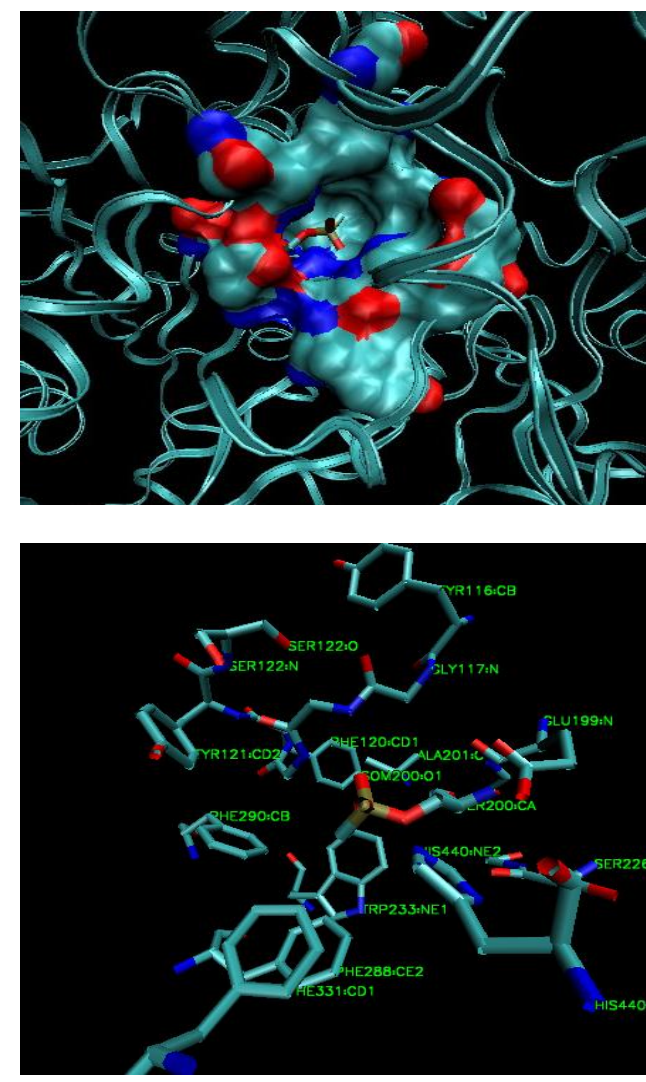

Fig. (5) the active site of the complex somanAChE
Six of 14 aromatic amino acid residues lining in the active site gorge of AChE are replaced by aliphatic amino acid residues in $\mathrm{BChE}$. This situation causes the volume of $\mathrm{BChE}$ active site gorge is larger than that of AChE. The replacement of aromatic amino acids with aliphatic amino acids is also responsible for selective sensitivity against different inhibitor of the two enzymes. Three distinct domains in active site gorge confer selectivity for $\mathrm{AChE}$ and BChE inhibitors: first domain is acyl binding pocket. Studies with the mutant BChE were showed that Leu and Val residues are responsible for binding of larger substrate and selective iso-OMPA inhibition. Replacement of these residues with phenylalanines as found in the case of AChE makes it prefer smallest substrates and so iso-OMPA is not an inhibitor of AChE. Second domain is found near the lip of active site gorge. At this domain of AChE, Tyr72, Tyr124 and Trp286 have critical role for binding of BW284C51. Third domain was defined as the choline binding site (or cation- $\pi$ site). Tyr337 and Trp82 at this site are responsible for sensitivity to ethopropazine in BChE.

Ser, His, Trp and 2Glu residues have the great role in the catalytic function for both enzymes although there is a difference in the sequence of the residues in both of them.

The distances between the inhibitor (soman) and the important residues in the active site are tabulated in the tables $1 \& 2$ for the complex of soman and AChE and $\mathrm{BChE}$ enzymes respectively. It is clear from tables $(1 \& 2)$ that the distance between the inhibitor and the serine residue in the active site is very low. 
Table 1: The distances of soman and some important residues in the active site of the complex soman-AChE.

\begin{tabular}{|c|c|}
\hline Bonds & Distance $(\AA)$ \\
\hline Ser $200:$ O $\gamma-$ Som $200:$ P1 & 1.53 \\
\hline His $440:$ N $\varepsilon 2-$ Som $200: 02$ & 2.64 \\
\hline His $288:$ C $\varepsilon 1-$ Som $200:$ C1 & 3.75 \\
\hline Trp 233 $:$ CH2 - Som $200:$ C1 & 3.90 \\
\hline Gly $119:$ N - Som $200: 01$ & 2.58 \\
\hline Gly $118:$ N - Som $200: 01$ & 2.76 \\
\hline Ala $201:$ C $\beta-$ Som $200: 01$ & 3.51 \\
\hline Ala $201:$ N - Som $200: 01$ & 3.03 \\
\hline
\end{tabular}

Table 2: The distances of soman and some important residues in the active site of the complex soman-BChE.

\begin{tabular}{|c|c|}
\hline Bonds & Distance $(\AA)$ \\
\hline Ser $198:$ O $\gamma-$ Som $601:$ P1 & 1.60 \\
\hline His $438:$ N 2 2 - Som $601:$ O2 & 2.86 \\
\hline Gly $117:$ N - Som $601:$ O1 & 2.56 \\
\hline Gly $116:$ N - Som $601:$ O1 & 2.69 \\
\hline Trp 231 : CH2 - Som $601:$ C1 & 4.04 \\
\hline Ala $199:$ N - Som $601:$ C1 & 2.79 \\
\hline
\end{tabular}

The difference between the molecular structure of the soman inhibitor in the figure 1 and its geometry in the active site is attributed to the degradation of this molecule in the active site through the nucleophilic reaction between the serine residue and the soman in the presence of His and Glu residues.

The mechanism of inhibition is similar to that of the cracking of the acetylcholine molecule. It is an example of the (charge relay) system. Imidazol ring of His438 relays electrons from Glu325 to Ser198 and hydroxyl oxygen of Ser198 becomes a nucleophile. Nucleophilic attack of this hydroxyl oxygen to ester bond of substrate leads to the formation of the acyl-enzyme intermediate and free choline moiety. Then acyl group is hydrolyzed from Ser198 by nucleophilic attack of a water molecule activated by taking a proton from His 438 in the case of acetylcholine while in the case of soman the nucleophlic attack is happened on the phosphorus atom to give phosphate-enzyme and free the organic part of soman but here the activated water can not free the phosphate from the serine residue..

The degradation results ((RO-P) bond cleavage) are two parts, the phosphate part which makes a stable bond with serine residue as shown in the tables $(1 \& 2)$ and figures $(4,5)$ and to predict the second organic part we calculated the energy and the geometry optimization for some molecules we expected to be the second part of the degradation result for the inhibitor, through the structure of the soman molecule and the rearrangement steps.

The PM3 calculations for these results are shown in the table (3) and figure (6) show the reaction path. The third reaction path which has the lowest energy and gives the alkyl alcohol molecule is expected to be the second organic part of the result of degradation.

Table 3: The energy of the degradation reaction results of the soman in the active site as calculated by the PM3 program.

\begin{tabular}{|c|c|}
\hline molecules & Energy $(\mathrm{kcal} / \mathrm{mol})$ \\
\hline Soman & -6.84473 \\
\hline 2,3-dimethyl-1-butene & -12.44806 \\
\hline 2,2-dimethyl-2-butanol & -78.96277 \\
\hline 2,3-dimethyl-2-butene & -21.94981 \\
\hline
\end{tabular}




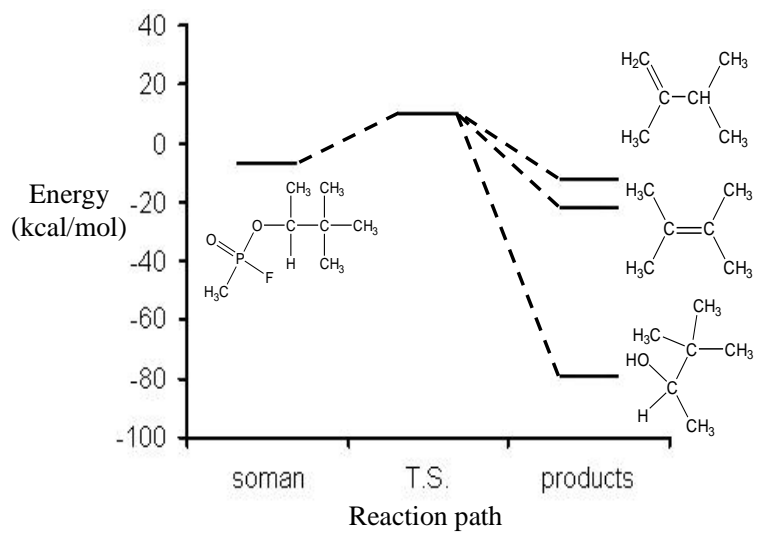

Figure (6) the reaction path

The sigma bond formed between the phosphorus part and the serine residue shown in tables $1 \& 2$ ends the catalytic activity for these enzymes and we expect that this is the mechanism of inhibition.

\section{References:}

1. Massoulie, J., Pezzementi, L., Bon, S., Krejci, E., Valette, M., (1992) "Molecular and cellular biology of cholineterases", Neurobiology 41, 3191.

2. Massoulie, J., Sussman, J., Bon, S., and Silman, I., (1993) Prog. Brain Res. 98, 139-146.

3. Meshover, E., Erb, C., Gazit, R., Pavlovsky, L., Kaufer, D., Friedman, A., Gliek, D., and Soreq, H., (2002) Science 259, 508-512.

4. Behra, M., Cousin, X., Bertrand, C., Vonesch, J., Biellmann, D., Chatonnet, A., and Strahle, U., (2002) Nat. Neurosci. 5, 111-118.

5. Chatonnet, A., Lockridge, O., (1989) "Comparison of butyrylcholinesterase and acetylcholinesterase", Biochem. J. 260, 625-634.
6. Quinn, D., (1987) Chem. Rev., 87, 955979.

7. Chatonnet, A., and Lockridge, O., (1989) Biochem. J., 260, 625-634.

8. Mack, A., and Robitzki, A., (2000) Prog. Neurobiol. 60, 607-628,

9. Ryhanen, J

"Pseudocholinesterase activity in some human body fluids" Gen. Pharmacol. 14, 459-460.

10. Lockridge, O., and Masson, D., (2000) Neuro toxicology 21, 113-126.

11. Dave, R., Syal, R., Katyare, S., (2000) "Tissue cholinesterases, A comparative study of their kinetic properties", $Z$. Naturforsch. 55c, 100-108.

12. Allon, N., Rareh, L., Gilat, E., Cohen, E., Grunwald, J., and Ashani, Y., (1998) Toxicol. Sci. 43, 121-128.

13. Broomfield, C., Maxwell, D., Solana, R., Castro, G., Finger, A., and Lenz, D., (1991) J. Pharmacol. Exp. Ther. 259, 633-638.

14. Raveh, L., Grunwald, J., Marcus, D., Papier, Y., Cohen, E., and Ashani, Y., (1993) Biochem. Pharmacol. 45, 2465 2474.

15. Cokugras,

A., (2003)

"Butyrylcholinesterase: structure and physiological Importance" Turk J. Biochem. 28(2) 54-61.

16. Guillozet, A., Smiley, J.F., Mash, D.C., Mesulam, M., (1997) "Butyrylcholinesterase in the life cycle of amyloid plaques" Ann. Neurol., 42, 909-918.

17. Mason, J., Waine, E., Stevenson, A., Wilson K., (1993), "Aging and spontaneous reactivation of human plasma cholinesterase activity after inhibition by organophosphorus pesticides", Hum. Exp. Toxicol. 12, 497-503. 
18. Raveh, L., Grunwald, J., Grunwald J., Cohen, E., and Ashani, Y., (1997) "The stoichiometry of protection against soman and VX toxicity in monkeys pretreated with human butyrylcholinesterase" Toxicol. Appl. Pharm. 145, 43-53.

19. Allderdice, P., Garner, H., Galutira, D., Lockridge, O., LaDu, B., McAplines, J., (1991) "The Cloned Butyrylcholinesterase (BCHE) Gene Maps to a Single Chromosome Site" Genomics 11, 452-454.

20. Wright, C.I., Geula C., Mesulam M., (1993) "Neurological cholinesterases in normal brain and in Alzheimer's disease: Relationship to plaques, tangles and pattern selective vulnerability" Ann. Neurol., 34, 373 384.

21. Choudhary, M., Nawaz, S., Atta-urRahman, (2005), "Juliflorine: A potent natural peripheral anionic-site-binding inhibitor of acetylcholinesterase with calcium-channel blocking potential, a leading candidate for Alzaheimer's disease therapy" Biochemical and Biophysical Research Communication 322, 1171-1179.

22. Bartus, R., Dean, R., Beer, B., (1982), " The cholinergic hypothesis of geriatric memory dysfunction", Science, 217, 408-414.

23. Bartus, R., (2000), "On neurodegenerative diseases, models, and treatment strategies: lessons learned and lessons forgotten a generation following the cholinergic hypothesis", Exp. Neurol., 163, 495529.

24. Belluti, F., Rampa, A., Piazzi, L., Bisi, A., Gobbi, S., Bartolini, M., Andrisano, V., (2005), "Cholinesterase inhibitors: xanthostigmine derivatives blocking the acetylcholinesteraseinduced $\beta$-Amyloid aggregation", 48 , 4444-4456.

25. Raveh, L., Grunwald, J., Marcus, D., Papier, Y., Cohen, E., Ashani, Y., (1993), "Human butyrylcholinesterase as a general prophylactic antidote for nerve agent toxicity: In vitro and in vivo quantitative characterization", Biochem. Pharmac. 45, 2465-2474.

26. Kass, J., Fusek, J., (1997), "Effect of panpal pretreatment and antidotal treatment (HI-6 plus benactyzine) on respiratory and circulatory function in soman-poisoned rats", Hum. Exp. Toxicol. 16, 563-569.

27. Stains, K., SYBYL,(1999), molecular modeling software, Tripos Associate Ltd., St. Louis, MO.

28. Humphrey, W., Dalke, A., Schulten, K., (1996), "VMD-Visual molecular dynamics", J. Mol. Graph. 14, 33-38.

29. Kryger, G., Harel, M., Giles, K., Toker, L., Velan, B., Lazar, A., Kronman, C., Barak, D., Ariel, N., Shafferman, A., (2000) "Structure of Recombinant Native and E202Q Mutant Human Acetylcholinesterase Complexed with Snake Venom Toxin Fasciculin-II" Acta Crystallogr., Sect. D: Biol. Crystallogr., 56(11), 13851394.

30. Stewart, J., (1989), "Optimization of Parameters for Semiempirical Methods I, Method", J. Comput. Chem. 10, 209-220.

31. Goodford, P., (1985)," GRID program", Journal of Medicinal Chemistry, 8, 52-56. 


\section{دراسة المعقدات الناتجة لغاز الأعصاب السومان مع أنزيمات الاسيتايل كولين استريز والبيوتيريل كولين استريز التيزي}

$$
\text { محمد عبل الله**** }
$$

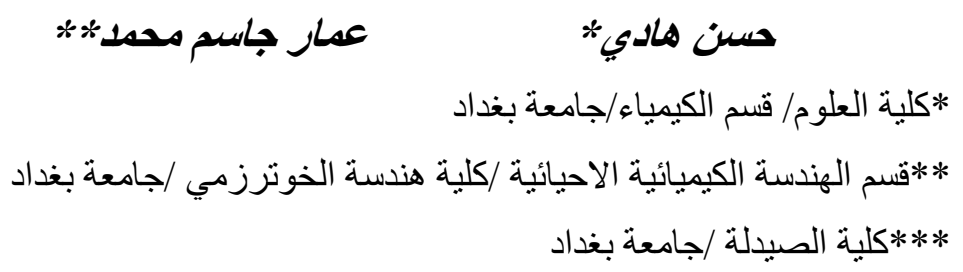

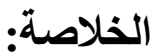

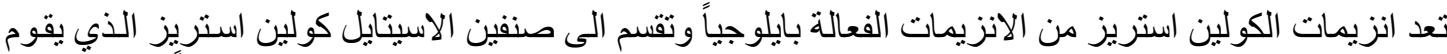

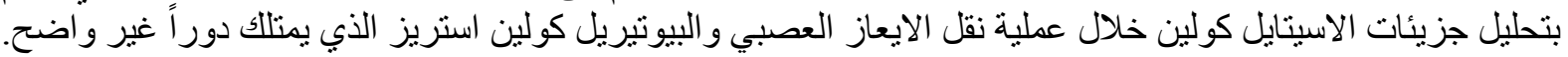

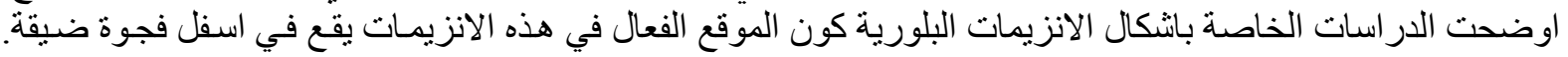

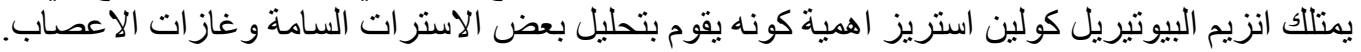

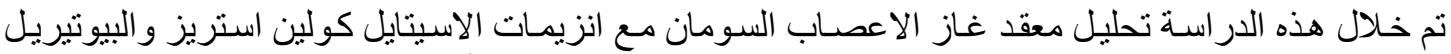
كولين استريز ونم وصف شكل هذه المعقدات و الموقع الفعال فيها و التغير ات التي تطر أ عليها خلال عملية التنبيط ومحاولية وصف ميكانيكية هذه العملية. تعاني جزيئة السومان تكسيراً في الموقع الفعال في كلا الانزيمين ثم حسـاب طاقة نواتج هذا التفاعل و اقتر اح مسلك التفاعل. بينت هذه الحسابات اتحاد ناتج تفاعل التكسير مـع ثمالة السيرين في الموقع الفعال وتكون اصرة مستقرة تنهي الفعالية الانزيمية لهذه الانزيمات. تعود اهمية هذه الدر اسة الى كونها اساس في البحث عن جزيئات مثبطة تساهم في علاج مرض الزهايمر. 